\title{
DEVELOPING A NEW TOURISM FORM: CASE STUDY ON THE ANIMATED MOVIE BATTLE OF SURABAYA
}

\author{
M. Suyanto* \\ AMIKOM University \\ Jalan Ring Road Utara, Yogyakarta, Indonesia \\ *yanto@amikom.ac.id
}

\begin{abstract}
This paper deals with how AMIKOM University through MSV Pictures has been the center for animators since the movie "Battle of Surabaya (November 10th)" as the first 2D Indonesian animated movie was launched. The animated movie fans who rushed to visit the campus to find out how to produce and watch the movie constituted as a new tourism form. The fans of Battle of Surabaya came from all over the world. The Battle of Surabaya achieved several international awards, namely: Best Animation (Milan International Filmmaker Festival of World Cinema, 2017); Best Animation (Berlin International Filmmaker Festival of World Cinema. 2017); Best Animation (Nice International Filmmaker Festival of World Cinema. 2017); Gold Remi Award (The Houston International Film Festival. 2016); Grand Prize (Seoul International Cartoon and Animation Festival 2016); and Best Animation (Noida International Film Festival. 2016). Battle of Surabaya entered the United States, UK and China markets. The film could create a positive impact on animation tourism that gained momentum as it did in Japan. As a result, the campus received the interest of both domestic and foreign tourists to come to the campus. AMIKOM University, together with MSV Pictures, Sleman Government and Sleman Creative Community succeeded in making Sleman selected as the City of Animation, Film and Video by Creative Economy Agency.
\end{abstract}

Keywords - New tourism; Animated films; Battle of Surabaya; AMIKOM university; Nation Competitiveness

\section{INTRODUCTION}

In the midst of the rapid development of information and communication technology, especially with the ever-increasing Internet users, individual communication skills have improved markedly, thereby altering the various forms of communication that can affect tourism destinations. According to the World Internet Stats on June 30, 2017, world Internet users reached more than 3.88 billion, while Internet users in Indonesia reached more than 132 million [1]. The younger generation in this situation forms a private community segmented through social networks. The survey results conducted by Mastel and the Indonesian Internet Association Association in June 2016, to 1,020 respondents in Indonesia of younger generation aged less than 19 years (15\%), aged 19 years to 36 years $(82 \%)$ and aged 37 years to 50 years $(3 \%)$ using the internet every day more than 6 hours reached $55.39 \%$, and 2 hours to 6 hours as much as $40.77 \%$. Social media users reached $95.10 \%$ and social media used Instagram 82.6\%, Facebook 66.5\%, and Pinterest 49.6\%. 
Internet connections used with cell phones reached 54.02\%; with WIFI, 40.29\%; and with cable, 5.69\% [2]. The dramatic changes in communication activities and the formation of various communities based on the common usage of the Internet, greatly changed the tourism patterns of the youth, who enjoyed new trends, and who also created a huge impact on the development of local tourism. The conventional model of watching movies in the theaters is limited. Terrestrial and satellite broadcasting also involves time constraints. Nowadays the development of the Internet enables people to enjoy watching television programs or movies anytime and anywhere as they like. This situation makes animation movies more popular, young fans can watch them through on-line video-sharing sites beyond national borders and exchange information on the Internet. In recent years, there has been a growing trend for tourists who visit places associated with animated films or television series in Japan. There has been, however, not many researches to examine such animation-induced tourism, although some Japanese researchers have started to investigate its phenomenon empirically. Such contemporary information-sharing among these fans creates cross-border travel in the form of an anime "pilgrimage." Anime enthusiasts find locations where animations were shot and other places related to their creators, cherish them as "holy places" and enjoy visiting those special spots [3].

Therefore, this paper deals with how AMIKOM University through MSV Pictures has been the center for animators since the movie "Battle of Surabaya (November 10th)" as the first 2D Indonesian animated movie was launched where it is considered as a development of a new tourism form. We will show that the Battle of Surabaya (November 10th) achieved several international awards and has entered the United States, UK and China markets, has the allure to bring tourists to AMIKOM University, supporting national competitiveness [4].

The rest of this paper is organized as follow: Section 2 presents rudimentary on movie and animation. Section 3 presents the proposed approach. Section 4 presents obtained results and following by discussion. Finally, Section 5 concludes this work.

\section{RUDIMENTARY}

There are several ways of attracting potential travelers ranging from television commercials, newspaper and magazine ads, tourism exhibitions, online advertising, and mobile ads to movies. Public authorities involved in the promotion of tourism, explore the way through which movies function as leverage for boosting tourism traffic [5]. With recent box office successes of films and television dramas which led to the boom of film mediainduced tourism, there is a growing trend of scholastic research in exploring film's motivational power to promote tourism in certain countries. Two most often quoted are package tours to the Middle Earth film locations in Peter Jackson's Lord of the Rings trilogy in New Zealand, and visits to the Dae Jang Geum Theme Park in South Korea, where the series Jewel in the Palace was produced. A commonly discussed issue in mediainduced tourism has been how a country should develop its tourist industry based upon influences of successful films produced [6].

In Indonesia, one of the ways to attcract tourists makes use of the locations where the movies have been made, for example, Blackhat, an American action thriller starred by Chris Hemsworth (cast of Thor in Thor and The Avengers), directed by Michael Mann, who would like to combine digital sophistication and Asian nuance, which makes the storyline involve countries in Asia, including Indonesia. Michael Mann said that Indonesia is a very interesting place where there are many traditions from various ethnic and it becomes the largest Muslim country in the world. Mann wants to showcase something epic in his movie and make Balinese culture one of the main stages. In today's popular media-driven society, there has been a growing interest in filming sites as tourist destinations. A wide availability of and repeated viewing opportunities for movies and television programmes have facilitated a new form of tourism, film-induced tourism [7]. In Japan, some of anime fans 
make "Anime Pilgrimage" which is a kind of tourist behavior. People making an "Anime Pilgrimage" are called "Anime Pilgrims". They make a pilgrimage to "Mecca for Anime Fans". This is tourism destination for "Anime Pilgrim". "Mecca for Anime Fans" is location for anime and being accepted as valiant place by anime Fans. Today, "Mecca for Anime Fans" scatters around the country [8].

One of the main intensions of "Anime Pilgrimage" is to shoot the scenic photos of "Mecca for Anime Fans". In many cases "Mecca for Anime Fans" is detected by anime lovers although anime production does not specify the precise location being used for background of anime. Pioneering "Anime Pilgrim" put out the information of "Mecca for Anime Fans" on the Internet [9]. Battle of Surabaya as the first 2D Indonesia animated film has the allure to bring tourists to AMIKOM University [4]. To understand the development of a new tourism form in the case study on the animated film, "Battle of Surabaya", the research was focused on how and on what are the roles of the animated film, "Battle of Surabaya", to develop a new tourism form, the impact on local environment, and the enhancement of national competitiveness.

\section{PROPOSED APPROACH}

To answer the objective of this work, a longitudinal case study approach where the objectives and activities that led to the creation of a new tourism form from the animated film, Battle of Surabaya, was made from 2009 to 2017. Several reasons to choose Battle of Surabaya, as the object of research are as follows: (i) Battle of Surabaya has gained more than 10 international awards; (ii) Battle of Surabaya is the first Indonesia 2D animated film; (iii) Battle of Surabaya is the first Indonesian animated film entering the global market; and (iv) Battle of Surabaya has attracted a large number of foreign and domestic tourists to visit AMIKOM University and MSV Pictures, where the film was made. According to Yin in [10], a case study is the most applicable method for investigating "a contemporary phenomenon within its real-life context, especially when the boundaries between phenomenon and context are not evident." Furthermore, the case study methodology has a major role in building theories, being considered by Eisenhardt and Graebner [11] as the most important bridge "from rich qualitative evidence to mainstream deductive research."

We collected secondary data from scientific papers; UNESCO Report 2009, from the institutional documentation, such as profile, web pages, and press conferences [12]. Founder of Creative Economy Park was able to describe the development of the park in detail because he is an active actor of all periods of development of the park [13]. We also interviewed the University's founders, CEO of MSV Pictures, community founders, entrepreneurship centers and AMIKOM University officials.

\section{RESULTS AND DISCUSSION}

Mataram Surya Visi Ltd. was established on June $19^{\text {th }}, 1993$, running a business, and providing service in outdoor advertising. In 2000, the business developed for indoor advertising including TV commercial advertisements. In the same year the business expanded and became a Production House which was developed from its previous advertising service, as well as consulting services, company profile production and also post production service for TV stations. In year 2002 the business developed into animation film production as a research project. The result of this research is used for enfolding the animation film of AMIKOM University in Yogyakarta. Apart from that, it was also used for serving the govermental necessities in expanding animation in Indonesia. In the development of a new tourism form in the case study on the animated film, Battle of Surabaya, there are three stages, namely: before the production process, during the production process, and after the launching of the film [13]. Groups of Animated film visitors that have come to AMIKOM University and MSV Pictures can be seen in Table I below. 
Table I. Groups of Animated film visitors that have come to AMIKOM University and MSV Pictures

\begin{tabular}{|c|c|c|c|c|c|c|c|c|c|c|c|}
\hline Domistic Tourists & 2009 & 2010 & 2011 & 2012 & 2013 & 2014 & 2015 & 2016 & 2017 & Total & Percentage \\
\hline $\begin{array}{l}\text { University and } \\
\text { College }\end{array}$ & 4 & 13 & 23 & 21 & 37 & 28 & 28 & 45 & 85 & 257 & 18.6 \\
\hline $\begin{array}{l}\text { Senior and Junior } \\
\text { High School }\end{array}$ & 6 & 25 & 45 & 75 & 111 & 149 & 182 & 178 & 192 & 962 & 69.7 \\
\hline $\begin{array}{l}\text { Elementary School } \\
\text { and Kinder Garden }\end{array}$ & 0 & 6 & 2 & 2 & 3 & 3 & 4 & 3 & 7 & 29 & 2.1 \\
\hline Government & 0 & 1 & 1 & 0 & 3 & 2 & 8 & 9 & 18 & 42 & 3.0 \\
\hline $\begin{array}{l}\text { Private and } \\
\text { Community }\end{array}$ & 0 & 0 & 1 & 2 & 1 & 1 & 4 & 10 & 19 & 38 & 2.8 \\
\hline \multicolumn{12}{|l|}{ Foreign Tourists } \\
\hline All Institutions & 0 & 0 & 2 & 0 & 2 & 6 & 6 & 11 & 26 & 53 & 3.8 \\
\hline Total Group & 10 & 45 & 74 & 100 & 157 & 189 & 132 & 253 & 347 & 1381 & 100 \\
\hline Total Visitors & 434 & 3767 & 5417 & 10023 & $\begin{array}{c}1465 \\
3\end{array}$ & $\begin{array}{c}1514 \\
7\end{array}$ & $\begin{array}{c}1912 \\
1\end{array}$ & $\begin{array}{c}1957 \\
6\end{array}$ & $\begin{array}{c}2432 \\
8\end{array}$ & $\begin{array}{c}11247 \\
6\end{array}$ & \\
\hline
\end{tabular}

\subsection{EVELOPING A NEW TOURISM FORM: BEFORE THE PRODUCTION PROCESS (2009-2012)}

Before the production process of the animated film, Battle of Surabaya, developing a new tourism form at AMIKOM University was not too highlighted, because the tourists visiting AMIKOM University could see the operations of several commercial enterprises, namely: television channels, radio channels, cartoon production, software design, internet services, advertising, computer systems, consultancy and mobile networks [12]. When the tourists visited AMIKOM University, AMIKOM University also presented a number of a short animations, made by MSV Animation, namely: The Adventure of Abdan with the episode kite, which was awarded with Top 10 International Urbanimation 2008; Good Bye World; and Brigadier Dorman, which was also awarded with Nominated Indonesia ICT Award 2009. After seeing the films, the tourists also wanted to see the studio of MSV Animation. The number of the animation film tourists who visited AMIKOM University at the end of December 2009 only reached 484 people in one year. In 2010, MSV Animation changed its name to MSV Pictures and started working on international projects making 3D Computer Animation Feature Films "Ajisaka: Fire and Ice". The film was written and directed by Tristan Strange (New Zealand). In the same year, a cooperation with Kompas TV for the TV series "Abdan's adventure" was arranged. The number of the animation film tourists who visited AMIKOM University at the end of December 20010 reached 3767 people in one year (See Figure 1).

In 2011, the short animations of MSV Pictures got several awards, namely: 5 Nominated Indonesia ICT Awards, and Top 10 Animafest 2D Short Animated Film MNCTV. The number of the animation film tourists who visited AMIKOM University at the end of December 2011 increased to 5417 visitors. 


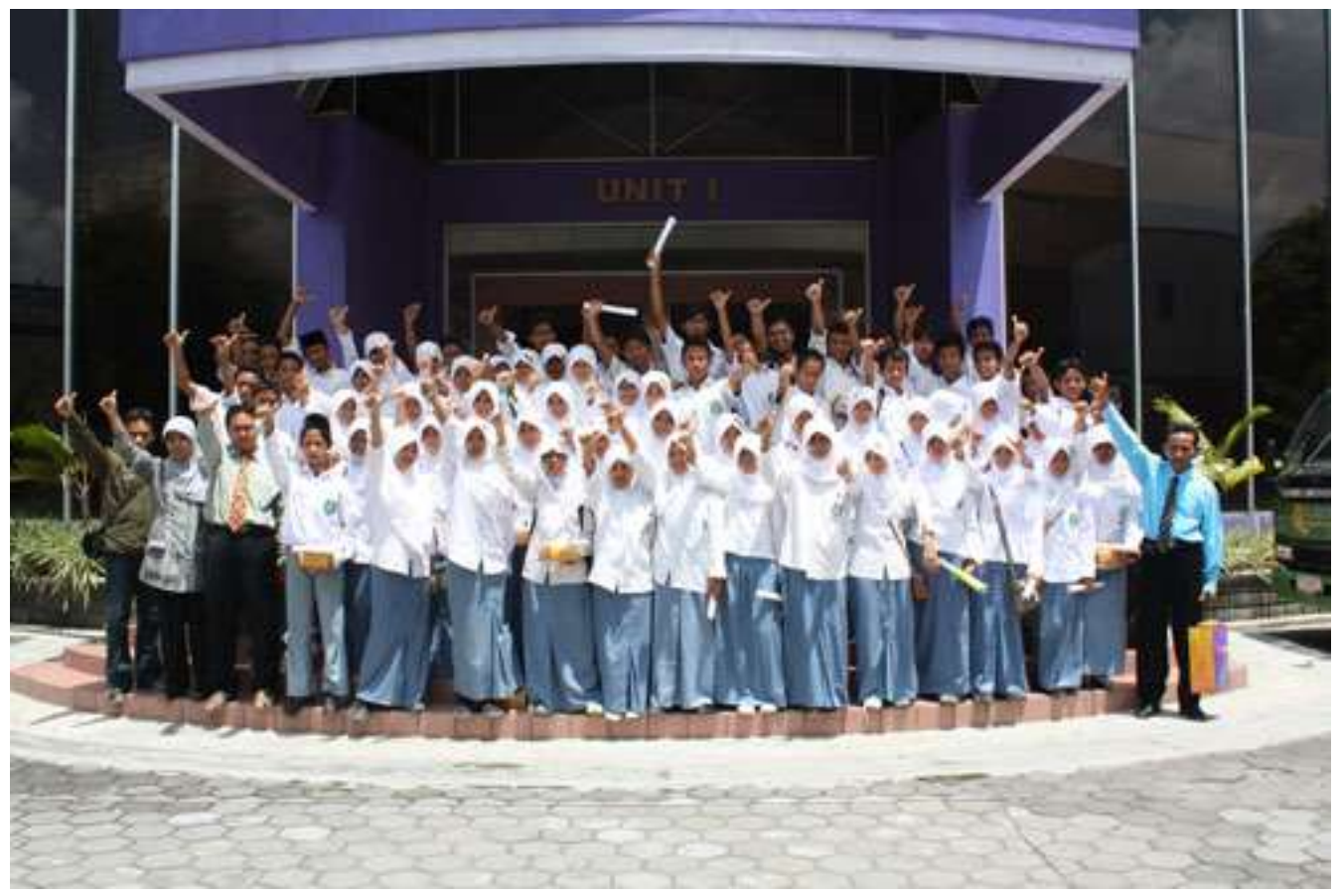

Fig. 1 A group of visitor to AMIKOM University

\subsection{DEVELOPING A NEW TOURISM FORM: DURING PRODUCTION PROCESS (2012-2015)}

The next stage was developing a new tourism form at AMIKOM University during the production process of Battle of Surabaya (See Figure 2). The production process of Battle of Surabaya comprises a number of stages, namely: development, pre production, production and post production. At the stage of development, Battle of Surabaya began in early 2012. The story of Battle of Surabaya was created by combining fiction and history based on field research on combat in Surabaya. After the story was finished, the manuscript, storyboard, and sound were recorded, and the trailer of Battle of Surabaya in Indonesian version was made. The trailer was the winner of Indonesia ICT Award in the category of digital animation, and the winner of INDIGO FELLOWSHIP, Category in Animation Film. In December 2012, the number of the animation film tourists who visited AMIKOM University for one year reached 10,023 people.

At the stage of pre-production of Battle of Surabaya, MSV Pictures launched Battle of Surabaya: The Movie on Facebook to communicate with its fans. Through Facebook, its fans began to be involved by asking the voice prompts of the main characters, namely Moses, Yumna and Danu. Based on the poll of the fans, finally the voice of Moses is that of Ian Saybani, the voice of Yumna is that of Maudy Ayunda, and the voice of Danu is that of Reza Rahadian. At the development stage, the location which was often visited by animation tourists was dubbing room of Maudy Ayunda and Reza Rahadian. The animation fans could also see videos of Maudy Ayunda and Reza Rahadian performing dubbing in the Cinema of AMIKOM University. 


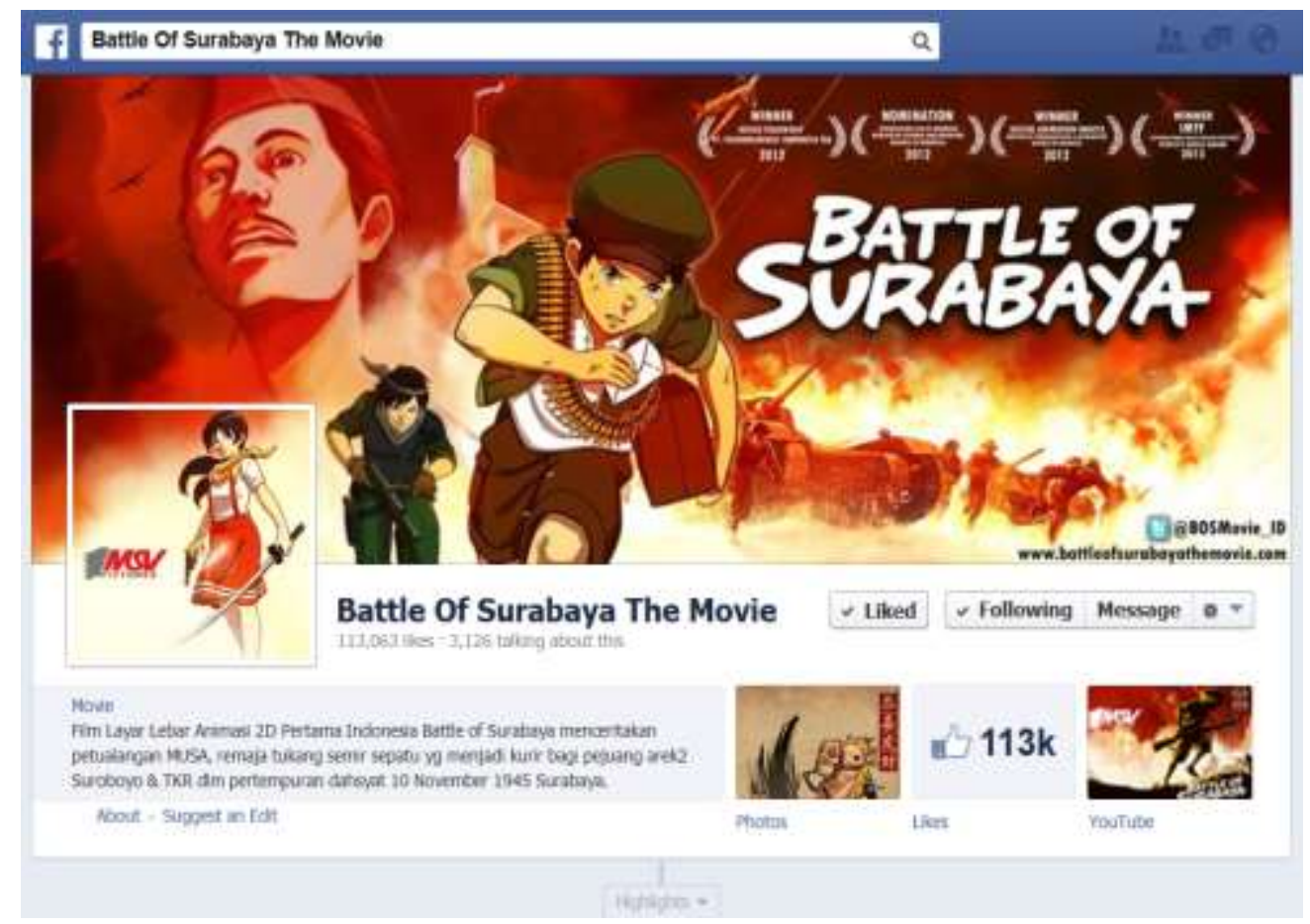

Fig. 2 Battle of Surabaya

In the same day, MSV Pictures uploaded the trailer of Battle of Surabaya in international version on Youtube. The trailer of Battle of Surabaya became trending topic on Youtube and reached 11,934 views whitin one day. It is hoped to be the pride of the Indonesian nation. Liputan 6 SCTV displayed the trailer of Battle of Surabaya, which had been uploaded on Youtube before. The production team of Battle of Surabaya carried out the Customer Social Responsibility program for senior high school students, that is to say, the students of Suriyothai School Thailand, SMK Tubam Indonesia, and the student forum as the lovers of animations and games from Malang. Figure 3 below depicts the student's visitor from Suriyothai School Thailand and SMK Tuban Indonesia

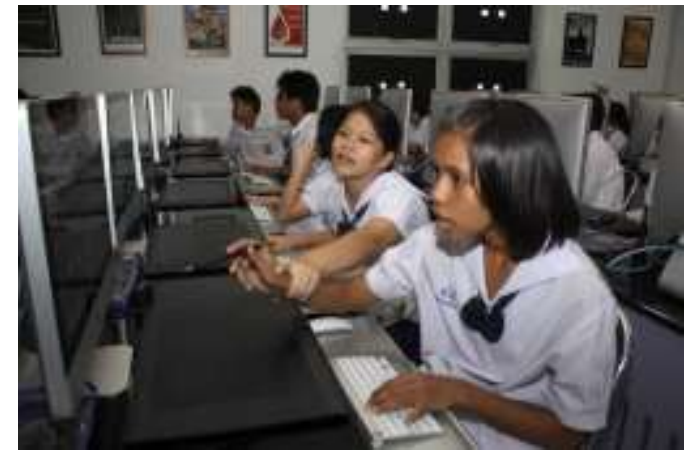

(a)

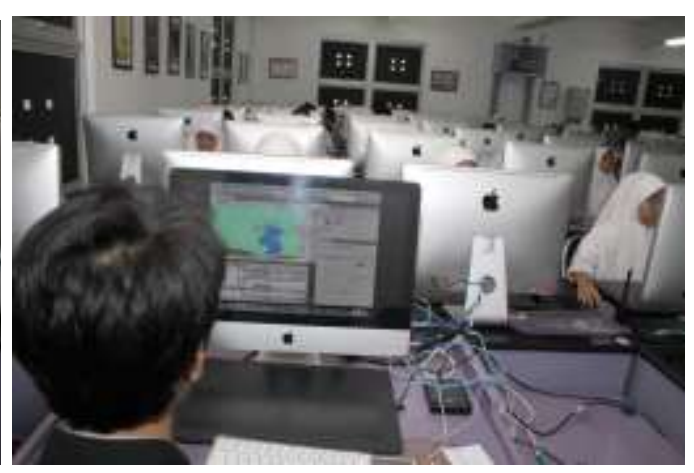

(b)

Fig. 3 Students visitors from Thaliand (a) and Local student (b)

In the pre-production stage, the Concept Art of the characters and background was designed in mid-2012, and it was based on the script. The animation fans were involved in holding fan art and cosplay contests. Figure 4 below presents the results of fan art contests. 

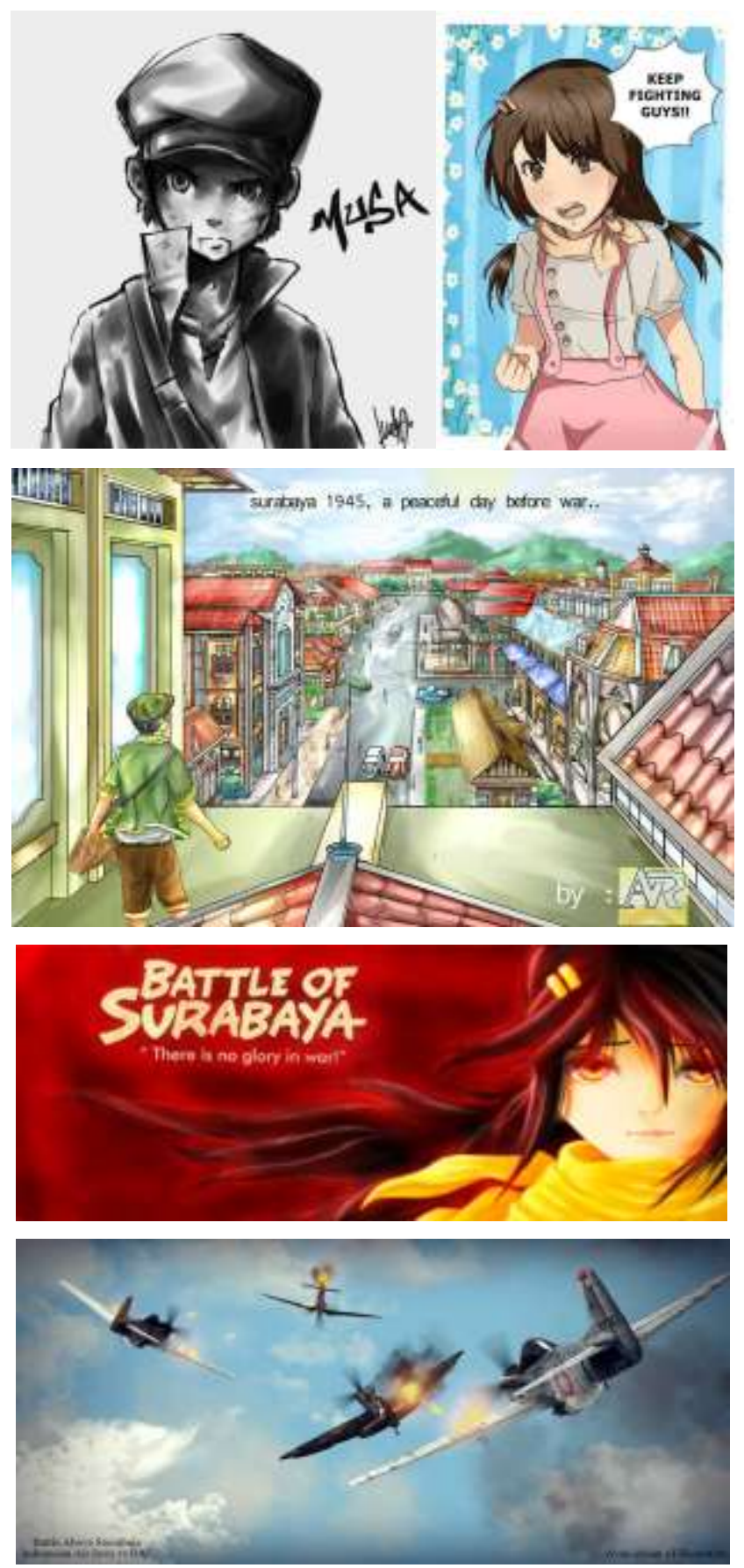

Fig. 4 Results of fan art Contests

In 2013, Media Indonesia newspaper announced the making of the animated film, Battle of Surabaya, which touches on Nationalism, and Kedaulatan Rakyat newspaper also published the dubbing selection for Battle of Surabaya. Battle of Surabaya, which was also displayed in Baros International Animation Festival in Cimahi, West Java, seized the attention of the participants. Moreover, the film that has been talked about a lot after appearing on the Internet achieved a number of awards. Baros International Animation Festival was joined by animators from various countries, such as, the Netherlands, the Phillipines, and Egypt, displaying their works. The event conceived by Cimahi Creative Association received a good response from the visitors, especially the animation lovers. Visitors could also see the process of animation making and gain knowledge on the process 
of animation works. Battle of Surabaya was also publishe by Liputan6.com and by Liputan 6 Petang SCTV. The MSV Pictures entered for the Anime Festival Asia (AFA), which is Asia's biggest anime festival in Jakarta on $6^{\text {th }}-8^{\text {th }}$ September 2013, and it was all published in Cinemags magazine in the edition of September 2013. Then, MSV Pictures followed Hello-Fest and sold merchandise at Polar 1, Kompleks Kolam Renang Senayan Jakarta, and participated in Indonesia Digital Media Festival, IT Center Building of ITB Bandung on December 2013. ABC Australia preached Battle of Surabaya.

The trailer of Battle of Surabaya got Winner of People's Choice Award in International Movie Trailer Festival. The award involved the fans who voted for its trailer. In the end of December 2013, the number of the animation film tourists who visited AMIKOM University for one year reached 14,653 people. In January 2014, in the production stage, the name Mataram Surya Visi Ltd. was change into Mataram Surya Visi Sinema Ltd., and it totally became an animation film studio. In the same year, the Battle of Surabaya trailer gained Nominee of the Best Foreign Animation for the $15^{\text {th }}$ Annual Golden Trailer Award. On April 5 ${ }^{\text {th }}, 2014$, MSV Pictures launched a BOS tweeter, which included activities on Battle of Surabaya, which have been updated. Figure 5 below depicts Battle of Surabaya in Tweeter.

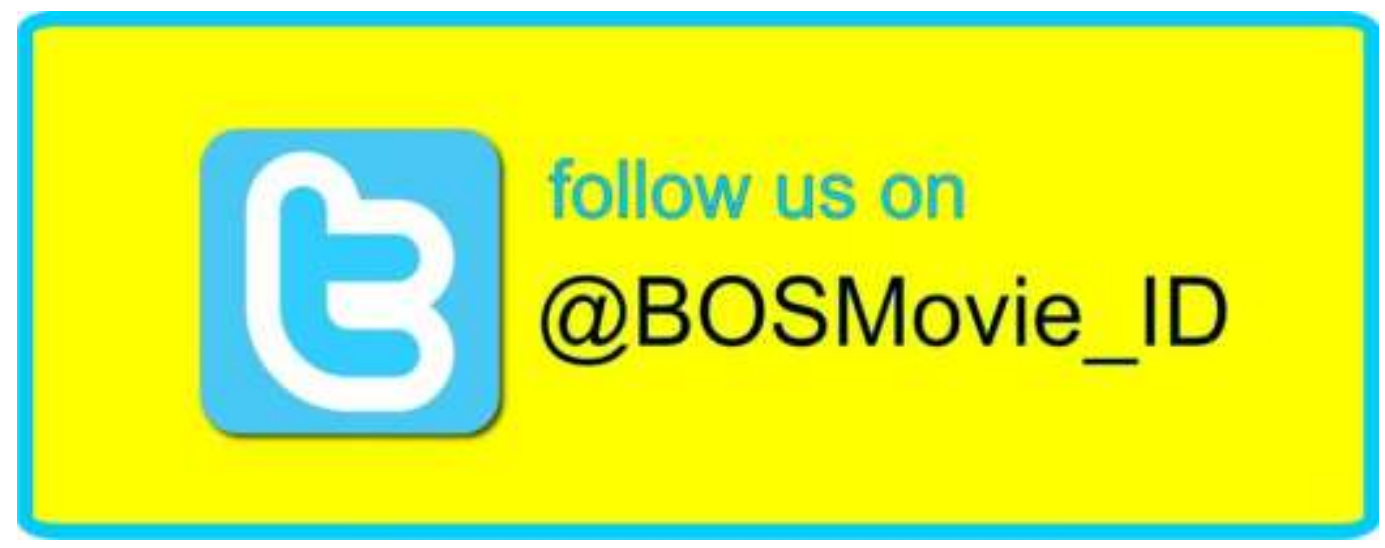

Fig. 5 Battle of Surabaya in Tweeter

On October $6^{\text {th }}, 2013$, the game Battle of Surabaya was launched to fulfill the demand of its fans. Figure 6 below depicts the cover of the Battle of Surabaya game.

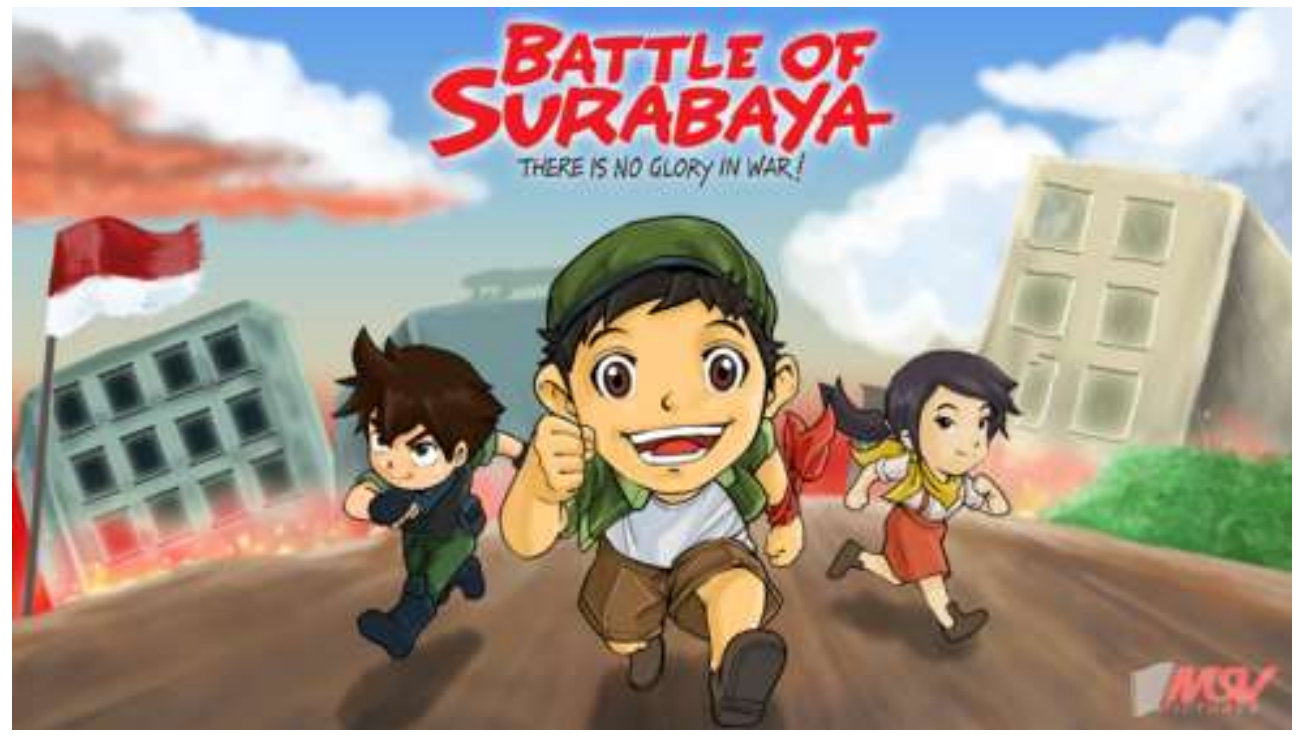

Fig. 6 Battle of Surabaya game 
At the end of December 2014, the number of the animation film tourists who visited AMIKOM University reached 15,147 people within one year.

\subsection{EVELOPING A NEW TOURISM FORM: DISTRIBUTION STAGE (2005 TO PRESENT)}

The next stage is the development of animation tours after of Battle of Surabaya was launched on Aougust 20 ${ }^{\text {th }}, 2015$. At the end of December 2015, the number of the animation film tourists who visited AMIKOM University reached 19,121 people within one year. In 2016, AMIKOM University, with MSV Pictures, presented Battle of Surabaya, which was attended by Minister of Research, Technology and Higher Education at Cinema AMIKOM University building.

Battle of Surabaya gained several international awards, namely: Gold Remi Award (The Houston International Film Festival. 2016); Grand Prize (Seoul International Cartoon and Animation Festival. 2016); and Best Animation (Noida International Film Festival. 2016). Battle of Surabaya (November $10^{\text {th }}$ ) took part in New Chitose Airport International Animation Festival 2016. This 2D animation-movie, together with Paprika, The Wind Rises and Tiger \& Bunny, was on New Chitose Airport, Sapporo, Hokkaido, Japan, on November $3^{\text {th }}-6^{\text {th, }} 2016$.

Aryanto Yuniawan, The Chief Executive Officer of MSV Pictures, attended the 2nd IBX 2016 as a panelist. This event was held by Association of Indonesian National Television (ATVSI) in South Jakarta on in the end of October 2016. The panel discussion, with the topic "The Power of Animation", attracted the most participants. Mr. Aryanto shared and discussed the production process of animated films, the ways to market the film, to be creative and innovative, and to successfully get participants' attentions from the very beginning, because animation is one of the potential arts that still have to be explored.

The series of Battle of Surabaya joined the event 10 Nopemberan, presented by INFIS (Surabaya Independent Films) and Animasub. This event was also in commemoration for the battle which happened in Surabaya on November 10th, 1945. Besides MSV Pictures, there were also other animation studios taking part in this event, such as, Culoboyo, Trio Hantu CS, Anak Nakal Production and Breadandbeyond. Under the theme of Wisata Animasi, 10 Nopemberan held animation movie screening produced by local studios, including the series of Battle of Surabaya. The series of Battle of Surabaya has been released on November 1 $1^{\text {st }}, 2016$ on YouTube. The first series entitled "Dureen!" tells about Yumna and Musa who find durians which are then stolen by Irul and Cak Sholeh, got more than 1000 hits within 24 hours of uploading.

MSV Pictures participated in Baros International Animation Festival (BIAF), an annual event held by the Government of Cimahi in association with Cimahi Creative Association (CAA), on November 17-20th 2016 located in Cimahi Technopark, West Java. Making the Battle of Surabaya the Series as the star in its booth, MSV Pictures successfully caught visitors attention during the event. The goal of this event is to build strong identity of Cimahi as Indonesia animation center. Baros International Animation Festival (BIAF) is where the stakeholders from showbiz industry come together, including animation studios, game developers, comic artists, illustrators, media, agencies, software developers, IT industry developers, and animation lovers' communities. At the end of December 2016, the number of the animation film tourists who visited AMIKOM University reached 19,576 people within one year.

Baros International Animation Festival was an animation festival held in Baros, Cimahi, West java, Indonesia. This festival, which accommodated all film genres, started in 2009 after Cimahi Creative Association (CCA) had been founded. It also proved how local government put so much attention on Indonesian animation development. The festival was held in Cimahi Technopark during October $6^{\text {th }}-8^{\text {th }}$, 2017. In this event, MSV Pictures was invited as a guest and a jury (from the Intelectual Property Creator) for Kid Cosplay Contest, the first kid cosplay contest in Indonesia. Aryanto Yuniawan, the director of Battle 
of Surabaya, was one of the juries. In this contest, participants should imitate a character's style and look. Figure 7 below depicts the Kid Cosplay Contest.
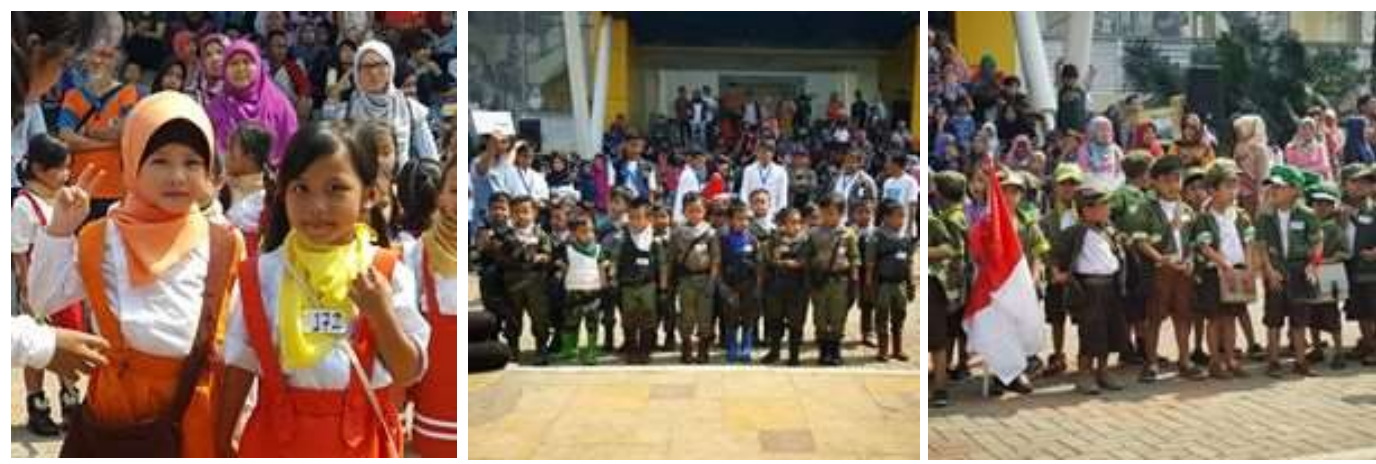

Fig. 7 Kid Cosplay Contest

Animpiade 2017 was the second event after it was held for the first time in 2015. Hanitianto Joedo, the director of Animpiade 2017 explained that this event also provided various agendas: seminar and discussion on animation movie development, animation workshop, animation competition, animation and comic exhibition, and games as well. In this event, MSV Studio was invited to open a booth on the expo for 5 days. MSV's booth presented information of the latest products and merchandise employing its brand-new design.

Battle of Surabaya gained several international awards, namely: Best Animation (Milan International Filmmaker Festival of World Cinema, 2017); Best Animation (Berlin International Filmmaker Festival of World Cinema. 2017); and Best Animation (Nice International Filmmaker Festival of World Cinema. 2017) [12]. Battle of Surabaya also entered the markets of the United States, UK and China, the markets which could significantly improve national competitiveness. The film could create a positive impact on animation tourism that gained momentum as it did in Japan [14,15]. As a result, the campus got the interest of both domestic and foreign tourists to come to the campus. AMIKOM University, together with MSV Pictures, Sleman Government and Sleman Creative Community succeeded in making Sleman selected as the City of Animation, Film and Video by Creative Economy Agency. At the end of December 2017, the number of the animation film tourists who visited AMIKOM University reached 24.328 visitors within one year, and it reached 112.476 visitors from 2009 to 2017.

\section{CONCLUSION}

The animated-film fans who rushed to visit the campus to find out how to manufacture and to watch the movie constituted a new tourism form. This paper has presented the development of a new tourism form: case study on the animated movie Battle of Surabaya. The results show that the groups of the animated-film tourists who visited AMIKOM University mostly from Senior and Junior High School were $69.7 \%$; and from University and College, $18.6 \%$. In the end of December 2017, the number of the animation film tourists who visited AMIKOM University reached 24.328 visitors within one year, and it reached 112.476 visitors from 2009 to 2017. The development of a new tourism form in the case study on the animated film, Battle of Surabaya, there are three stages, namely: before the production process, during the production process, and after the launching of the film. The film could create a positive impact on animation tourism that gained momentum as it did in Japan. As a result, the campus got the interest of both domestic and foreign tourists to come to the campus. AMIKOM University, together with MSV Pictures, Sleman municipal government and Sleman Creative Community succeeded in making Sleman selected as the City of Animation, Film and Video by Creative Economy Agency. 


\section{ACKNOWLEDGEMENT}

We would like to thank AMIKOM University for suppoting this work.

\section{REFERENCES}

[1] https://www.internetworldstats.com/stats.htm.

[2] Mastel and APJI. Konklusi Survey. Ekosistem DNA (Device, Network and Apps), Infografis Hasil Survey Mastel-APJI Nov 20, (2016).

[3] Yamamura, T. Anime Pilgrimage and Local Tourism Promotion: Experience of Washimaya Town the Sacred Place For Anime "Lucky Star" Fans. The International Conference On Impact of Movies and Television on Tourism, 21-23 May (2009).

[4] http://www.msvpictures.com/awards/ Retrieved 3 January (2018).

[5] Moira, P., Mylonopoulos, D., Kontoudaki, A. Using Film as a Tourism Promotional Tool: The Case of Greece, the International Conference on Impact of Movies and Television on Tourism, 21-23 May (2009).

[6] Chu, Kiu-wai. Touring In Slums and Ruins: Cinema of the Low and the Tourist Gaze-Induced Tourism, The International Conference On Impact of Movies and Television On Tourism, 21-23 May (2009).

[7] Iwashita, Chieko. Animation-Induced Tourism: A Case of "Heidi, a Giral of the Alps"-Induced Tourism, The International Conference On Impact of Movies and Television On Tourism, 21-23 May (2009).

[8] Okamoto, T Birth and Development of Anime Pilgrimage. Cultural Resource Management Research Team (Eds.), CATS Library Vol.1 Media Contents and Tourism: An Experience of Washimiya Town and Neon Genesis of Tourism (pp. 31-62). Sapporo, Center for Advanced Tourism Studies. (2009).

[9] Okamoto, T (2008). Discussion about Method for Investigation of Pilgrims' Behavior in "Sacred Place for Anime Fans": Validity of "Pilgrimage Note Analysis". Advanced Tourism Studies, 1: 1-13.

[10] Yin, R. K.; Case study research - Design and methods; 3rd Ed, Sage Publications, Applied Social Research Methods Series, Volume 5, (2003).

[11] Eisenhardt, K. M. \& Graebner, M. E.; Theory Building from Cases: Opportunities and Challenges; Acad. Manag. J., 50, 1, 25, (2007).

[12] Bjarnason, S., Cheng, K.M., Fielden, J., Lemaitre, M.J., Levy, D., \& Varghese, N.V.; A New Dinamic: Private Higher Education, UNESCO. World Conference on Higher Education, (2009).

[13] Suyanto, M. Developing Creative Economy Park at AMIKOM University, 2nd International conferences on Information Technology, Information Systems and Electrical Engineering (ICITISEE), (2017).

[14] Yamamura, T (2008). Study of Birth and Development of "Sacred Place for Anime Fans": Discussion of Tourist Promotions Based on Animated Work "Luckey Star" Focused on Washimiya, Saitama Prefecture. The Journal of International Media, Communication, and Tourism Studies, 7: 145-164.

[15] Yamamura, T., Okamoto, T., Matsumoto, S., \& Sakata, A. A study on the Impact of Animated Works on Tourism Development, Part.2: Development Process of LUCKY is STAR pilgrimage in Washimiya Town-Saitama and its visitors. Proceedings of Japan Institute of Tourism Research Annual Conference, 23, (2008): 353-356. 
International Journal of Control and Automation Vol. 12, No. 8 (2019) 